\title{
The Dilemma and Outlet of China 's High Education Management in the Era of Globalization
}

\author{
Li Gao \\ University for Science \& Technology, SiChuan 611745, China
}

Keywords: globalization, higher education, management, way out

\begin{abstract}
Under the background of globalization, China's higher education system is faced with a series of problems, such as management phy, system and mode is more backward, these problems are needed to find a way to solve urgently. In this paper, the author analyzes the higher vocational education in the background of globalization, and puts forward the corresponding solutions that we can learn from it.

At this stage, the economic exchanges of countries are deepening continually, cultural exchanges between countries are more and more important, which has brought new opportunities and challenges on China's higher education. The development of globalization has brought great influence of the higher education. The original teaching mode, teaching idea, management system and management mode have also been unable to meet the requirements of modern higher education. China must optimize the reform of higher education and create a higher teaching management system to satisfy the modern requirements.
\end{abstract}

\section{China 's Higher Teaching Background}

The time of China's higher education development is short, which is from the late Qing Dynasty when the government began to establish our first university - Beiyang University, then the Qing government has established a number of new schools, at the same time some students studied abroad to learn the advanced technology which is the mother batch of the students aboard. But unfortunately, these universities disappeared with the ruination of Qing Dynasty. The real prosperity of Chinese universities began in the period of the Republic of China, including Tsinghua University, Wuhan University, Zhejiang University and so on. After the founding of the PRC in 1949, the Chinese government has increased the establishment of the university, and later because of the rampant Red Guards, the state had to cancel the college entrance examination system, until 1978, the college entrance examination system was restored, it makes our higher education back on track, since then higher Education system has a smooth development [1]

\section{The Requirements of Higher Education in the Context of Globalization}

2.1 The Market Orientation Requirements of the Management System. At present, the higher education system must meet the requirements of the market mechanism under the era of globalization. The requirements of the market mechanism are as follows: (1) The university should be financially independent and increase its own market competitiveness and performance. In order to reduce the impact of national allocations on the university economy. (2) Private schools should expand their scale of education actively, attract the economic investment sources outside our countries. (3) Raising their own teaching conditions, attract more foreign students to the school, further develop the overseas education market [2].

2.2 The Requirements of the Management Concept. In the global context China's various cultures are more diversified, which requires our management concept on the colleges and universities to change. (1)Require our universities to be compatible with people that are from different regions, different countries, and has different living habits, different cultural ideas, which requires our colleges and universities can accommodate their own cultural practices, so that students from different regions and countries can live in a harmonious campus environment. (2)Require colleges and universities have the capability of independent innovation. A variety of cultural 
practices are also appeared in the campus, which not only requires the university itself with compatibility, but also need a college to absorb and innovate a variety of cultures, and formed the cultural concept which can be accepted by everyone ultimately, this innovative ability can ensure that colleges and universities are able to retain the nature, keep themselves in the impact of different cultural practices.

2.3The Requirements for the Management System. At this stage the government intervenes in colleges and universities much more than before, which restricts the development of the university. The founding concept of the university is different from high school, junior high school, its main purpose is to propagate and integrate the culture, too much government interference will make the university lose their own autonomy, lose the educational significance of higher education. There are many foreign schools management systems is worth learning, such as the Harvard in the United States, Cambridge, all these schools are private schools, the government also give less intervention, so these schools have more autonomy decision-making capacity.

2.4 The Networking and Transparent Management Model. With the continuous development of information technology, the social management model also changed from a certain degree, which also requires higher education made the appropriate changes and adjustments on their own management model and management methods. In the traditional process of higher education management, usually use the manual methods to carry out information collection and analysis, and there are many disadvantages, such as low efficiency [3]. With the further development of China's network technology, making the release time and space of information is no longer restricted to the traditional management mode, and expand the public access to information further.

\section{The Dilemma of Higher Education in the Background of Globalization}

3.1 Management Philosophy: Pay More Attention to the Plan While Ignore the Market. At present, in the daily colleges and universities management process, there are still some universities have the management philosophy which is focused on the planning while ignore the market, and lead it is difficult to form a fair and equitable educational environment in the process of higher education management. In addition, China's current higher education is mostly organized by the government, and lead some private institutions lack sufficient competitive advantage. In the process of investing in education in colleges and universities, many educational departments in China also have already moved resources towards key colleges and universities, and have led other colleges and universities have to devote their energies to the expansion of their own scale, the education function is difficult to get full play. Besides, some colleges and universities only focus on scientific research and infrastructure construction or other issues, and ignore their own educational functions directly, which will affect the level of education in colleges and universities in China directly.

3.2 Management did not do People-oriented. China's current educational philosophy is often based on the material-based, and therefore overlooked the people-oriented educational philosophy directly, its specific performance is in the following areas: (1) focus on the expansion of teaching scale, and decline in the requirements of education further; (2) focus on the students' derivative role, and ignore the role of educating people directly, lead to the dysfunction of university. (3) most of the investment are hardware investment, lack of attention to the software construction efforts. (4) emphasis on the science teaching but lack of importance on humanities teaching in the socialist teaching process.

3.3The University Management Model is More Rigid. In recent years although China's higher education has brought a certain degree of reform, and gave the sufficient autonomy on the institutions of higher education. However, in the course of the specific management of higher education, there are still some problems such as the backwardness of the provincial educational structure and the obsolete educational model, which leads to the existence of many problems in the higher education management mode at the present stage and that restricts the higher education of our country further development. 


\section{The Solution of Higher Education in the Background of Globalization}

4.1Establish the Correct Educational Philosophy. First of all we need to pay attention to the concept of "people-oriented" development, and take students as the main body of higher education management, teachers are required to set an example by their own action, and develop students' innovative ability fully in the teaching process. Second, we need to pay attention to the concept of "harmony without sameness". Among them, "harmony" requires that college managers are able to learn the management experience of other colleges in a peaceful and open minded way, and improve the inadequacies what are existed on their own management process, so that their own management level has been further improved [4]. And "difference" refers to learning from the experience of excellent institutions in the process, we also need to discard the dross select its essence, and maintain their own management characteristics fully

4.2 Improve the Management of Higher Education Model. First of all, China's education sector needs to change their own intelligence, and strengthen the macro-control of higher education. But in the choice of specific management practices, we need to change from the traditional direct management to indirect management, so that we can leave a certain degree of management autonomy for colleges and universities, and allow colleges and universities to allocate the resources rationally according to their actual situation. Second, managers of high education need to establish a contractual relationship between universities and government, and make full use of the law to set up their own professional science settings. In addition, institutions of higher learning also need to carry out the rationalization of management rules and regulations in accordance with the requirements of the relevant laws and regulations, it is the only way to further enhance the autonomy and normative institutions of higher learning, and effectively enhance the connection between colleges and universities and the society. This can make the university get continuous self-improvement in the daily process of management, and give full play to their own personnel training functions.

Summary: In the context of the globalization development, China's higher education which in order to achieve the further development, it must optimize and reform on their own management model, and we need to further increase the investment in education management. Only in this way we can promote the level of higher education in our country as well as further improve the conditions of operating a school, and give full play to China's higher education management functions, provide higher talent for the development of China's economy.

\section{References}

[1] Bao Chunhong, Wang Na. The Dilemma and Outlet of China's Higher Education Management under the Background of Globalization [J]. Hebei Enterprise, 2016, (2): 28-29.

[2] Lou Kun. Study on the Reconstruction of Higher Education Management Paradigm in the View of Public Management [J].Journal of Shandong University of Science and Technology (Social Science Edition), 2016,18 (3): 100-106.

[3] Huang Rongxia. University changes in the era of globalization (1980 - 2010) - the institutional origin of organizational transformation [D]. Huazhong University of Science and Technology, 2012.

[4] Ma Jianhua. The Dilemma and Outlet of China's Higher Education Management under the Background of Globalization [J]. Theater House, 2014, (9): 262-262,294. 